\title{
Balancing Inclusion and Diversity with Upholding Free Speech Rights in Canadian Universities: Challenging but Feasible
}

\author{
Sirvan Karimi ${ }^{1}$ \\ ${ }^{1}$ Assistant Professor, School of Public Policy and Administration, Faculty of LA\&PS, York University, Canada \\ Correspondence: Sirvan Karimi, Assistant Professor, School of Public Policy and Administration, Faculty of LA\&PS, \\ York University, Canada. \\ Received: May 31, 2021 \\ Accepted: July 2, 2021 \\ Online Published: July 8, 2021 \\ doi:10.5430/ijhe.v10n6p193 \\ URL: https://doi.org/10.5430/ijhe.v10n6p193
}

\begin{abstract}
The tension emanated from deeply polarized socio-cultural values has found its way into the Canadian university campuses. In their endeavour to strike a balance between promoting diversity, inclusion and respecting free speech, the Canadian higher educational institutions have encountered formidable challenges. Central to the contention revolving around the free speech debate is an assertion that institutional pressures for consolidating a culture of political correctness is believed to have the potential to curtail and stifle freedom of expression which has in turn triggered governmental intervention in certain Canadian provinces. The lack of a proper balance between the quest for promoting inclusion, diversity and free speech can in the long run undermine the socially vital mission of universities, and hence corroding the public trust in the higher educational institutions. Obviously, there is no single solution that can function as panacea to surmount these pressing demands faced by the Canadian universities. However, it will be argued that the extension of constitutionally protected freedom of expression to the Canadian universities is not only geared to address the shortcomings of academic freedom, but it is also conducive to harmonizing the pursuit of promoting diversity and inclusion with upholding free speech principles.
\end{abstract}

Keywords: academic freedom, Canadian higher education, freedom of expression, inclusion, political correctness, provincial governments, the charter, the courts

\section{Introduction}

Universities have historically been envisaged as the centers for the production, articulation, and dissemination of knowledge and ideas which are vital to the development of a well-functioning society. Central to this revered and crucial mission by the higher educational institutions in liberal democratic societies such as Canada, is academic freedom, which has established itself as the cardinal value in universities and colleges. Academic freedom is an essential mechanism that safeguards and facilitates the ability of educators to pursue truth and advance knowledge without fear of institutional reprisal. Universities are not only the sites for the development of knowledge but are also appropriate marketplaces of ideas. While higher educational institutions have been striving to promote diversity and inclusion, they have also come under pressure to foster a free speech environment where diverse perspectives and ideas can be freely expressed. Reconciling these two overarching societal values has become a conundrum for universities and colleges. It will be argued that promoting diversity and respecting free speech should not be interpreted as opposing principles. The extension of constitutionally protected freedom of expression to universities and colleges is not only conducive to redressing and strengthening academic freedom which fails to encompass students' free speech rights but is also geared to harmonize the quest for promoting diversity and inclusion with maintaining a vibrant and healthy exchange of ideas which is after all the raison de'etre of universities.

This paper is divided into three parts. Part one deals with the historical development of academic freedom in the Canadian universities. Part two is devoted to the methodology and literature review. In this section, survey results, data, and other relevant information on the state of free speech on the Canadian campuses will be discussed. Part three reflects on the interplay of academic freedom and freedom of expression and discusses how the application of Charter protected freedom of expression can harmonize promoting diversity and inclusion with upholding the rights to freedom of expression. Finally, main findings will be recapitulated in the concluding part of this paper.

\section{The Evolution of Academic Freedom}

Prior to analyzing the current state of academic freedom in the Canadian higher education sector, it is essential to 
discuss two major factors that had profound impact on the gradual institutionalization of academic freedom in Canadian universities, First, the emergence and consolidation of academic freedom in Canadian universities has taken a convoluted and rocky path. Second, the pressure and advocacy for the institutionalization of academic freedom in Canadian universities was mainly emanated from the progressive left and faculty unitions which played a crucial role in advancing the protection of academic freedom as a cherished value in the higher educational institutions (Robinson, 2019).

During the nineteenth century, the prevailing religious orthodoxy in Canada played a penetrating and ubiquitous role in shaping cultural, educational, and political life of the Canadian society. Due to vigilant role of religious institutions, deviation in teaching and scholarship that was contrary to the established creed was subject to harsh excoriation (Marshall, 1994; Horn, 1999). By the early decades of the twentieth century, while teaching and research gradually protected from religious interference, there was nonetheless no security for free speech outside classroom and hence criticism of higher educational institutions was susceptible to reprisals by university administrators (Horn, 1999).

Furthermore, in early decades of the twentieth century, even government had no qualm in intervening in the appointment process in universities. In other word, universities did not have an institutional identity since they were not autonomous and immune from undue political interferences. It was in fact due to political interference in the affairs of the University of Toronto, particularly, political influence in the appointment process which led to the establishment of the Royal Commission known as Flavelle Commission in 1906 (Davis, 2015). The findings and recommendations by the Flavelle Commission provided a rational framework for the adoption of a bicameral system as a mechanism to run university affairs. Based on this articulated model by the Flavelle Commission, two formally recognized bodies; Senate which was to be composed of faculty members and university administrator, and a board of governors were to be established (Davis, 2015, 65). University of Toronto was the first higher educational institution in Canada that adopted this model. Other universities gradually came to embrace this bicameral system of institutional governance (Jones, Shanahan \& Goyan, 2010).

Though the history of higher educational institutions can be traced back to the earlier time, their expansion and proliferation took place in 1960s and1970s. Economic growth, population explosion, enhancement of social mobility, and greater public pressure for mass access to educational opportunity contributed to the repaid expansion of universities in Canada (Hogan \& Trotte, 2013). The same socio-political forces also led to gradual expansion of faculty unionization across Canadian universities (Heron, 2015). Growing militancy of academia galvanized by progressive left put greater pressure on universities' administrators to extend collective bargaining mechanisms to the institutionalization of academic freedom (Robinson, 2019). It was in fact due to a strong reaction by the Canadian Association of University Teachers (CAUT) to the firing of Professor Harry Crowe by the United College (now University of Winnipeg) in 1959 that faculty associations across Canada were encouraged to include the language of academic freedom into their respective collective bargaining agreements (Dea, 2018). Thus, collective bargaining agreements became the main mechanism to secure academic freedom for faculty members to freely teach, conduct their research, and disseminate knowledge without the fear of sanctions by university administrators.

Academic freedom is difficult to define than to explain. Generally, it refers to the freedom that faculty members have in teaching and conducting research in order to explore and disseminate knowledge that contributes to the common goods of society. According to Barry Hogan and Trotter Lane (2013), academic freedom encompasses the following elements:

(a) the freedom to pursue truth wherever that may lead, (b) tenure so that the truth-seeker is not subject to loss of job when the research is controversial, (c) the ability of the scholar to be critical of the university, (d) the ability of the scholar to participate in public life, and (e) co-governance within the university (p.70).

As it can be extrapolated from the above quotation, tenure of employment became the main bulwark to protect faculty from fear of losing their jobs if their research findings were controversial and were not in line with administrators' perspectives. Furthermore, the bicameral system of institutional governance was designed to facilitate the involvement of faculty in university governance in order to shape workplace conditions conducive to protecting faculty rights including academic freedom (Johnston, 2017).

Unlike higher educational institutions in European countries and the United States where academic freedom is covered by the freedom of expression or speech protected by legislation or anchored in an entrenched constitution, academic freedom in Canadian universities is a negotiated right protected in collective bargaining between faculty unions and university administration (Robinson, 2019; Lynx, 2020). Prior to the first wave of faculty unionization in 
the Canadian post-secondary institutions in the 1960s and 1970s, academic freedom was vaguely codified in university policies and its protection was to a great extent dependent on the good will of university administrators (Robinson, 2019). Thus, faculty unionization agitated by progressive forces in labour movement became the main force behind the gradual consolidation of academic freedom in labour law. Unlike Europe and United States where dispute over academic freedom is invariably dealt with in the courts, disputes over academic freedom in Canada are mainly adjudicated through mandatory labour arbitration process where the decision is binding (Robinson, 2019; Lynx, 2020). As Michael Lynx (2020) has pointed out, the overall results of academic freedom arbitration have not been impressive for faculty across Canadian universities.

With growing pressure on universities' administrators to promote and safeguard diversity and inclusion, the debate over academic freedom has been intensified. University administrators have encountered a perplexing dilemma. While they are under enormous pressure for protecting diversity and inclusion, they have recently come under attack for failing to preserve freedom of expression. Thus, academic freedom has now come to be associated with freedom of expression which has in turn triggered major debate along the Left and the Right ideological perspectives.

\section{Free Speech on Canadian Campuses}

Though freedom of expression on university campuses has been a contentious issue since the early decades of the twentieth century, the debate over the fate of free speech in colleges and universities has recently acquired a growing currency. The contentious debate over whether there is a crisis of freedom of expression in Canadian universities has not only flared up in the media reporting but has also come to dominate academic discourse within university campuses as well.

It has been asserted by Conservatives and right-wing intellectuals that free speech is under severe threat and that colleges and universities can no longer be perceived as the champions of free speech (Ouellette \& Shaw; Brodie, 2019; Weismiller, 2011). According to this Conservative line of reasoning, the quest by university administrators to advance equity and promote inclusion has imposed severe restrictions on freedom of expression. In line with this Conservative narrative of free speech crisis, fear of administrative reprisal and cyber-bulling by active left-leaned groups on campuses have engendered a climate of consternation and hostility for Conservative and libertarian minded students and faculty who are coerced to impose self -censorship on themselves (Brodie, 2019).

Some authors have argued that the notion of free speech crisis in higher educational institutions is a manufactured myth concocted by Conservative and Libertarian intellectuals to counter the prevailing political correctness and identity politics that have gained ground in higher educational settings (Malik, 2019; Davies, 2018). It is asserted that Conservatives have exaggerated the decline of free speech in universities since they have realized that universities have become the main battleground against racism and all forms of exclusion in societies (Malik, 2019; Davies, 2018). According to this line of argument, free speech crisis crusaded by Conservative intellectuals is in fact a political manifestation of Conservatives' panic reaction to the fact that they have been losing grounds in political, ideological, and economic fronts (Davies, 2018). Consequently, it has been also suggested that Conservatives' narrative of widespread suppression of Conservative ideas is false and overblown (Franks, 2019).

It is a fatal flaw to outrightly deny the threat to freedom of expression in the Canadian higher educational settings. As Stephen Newman (2020) has point out, "...even if talk of a free speech crisis on American and Canadian campuses is overblown, the relatively small number of incidents that have occurred should be a cause for concern to anyone worried about the future of free expression" (p.27). Survey results, empirical and comparative studies aver and corroborate the assertion that freedom of expression is in fact being curtailed on Canadian university campuses.

One of the most detailed and comprehensive studies on the state of freedom of expression on Canadian campuses is provided by The Justice Centre for Constitutional Freedoms (JCCF, 2020). In its 2020 Campus Freedom Index report, it released an alarming information on the state of free speech on Canadian campuses. Based on four criteria, sixty-one public universities are assigned grade ranging from F to A. These four explanatory variables are; (a) clear and unequivocal commitment to advancing free speech as laid out in policy documents, (b) the absence of an express or implied speech code that prohibits or restricts speech on the ground of being offensive or discriminatory, (c) refusal to provide funding and other resources to groups or bodies that engage in ideological advocacy reflected in launching a vague and ambiguous campaign for inclusion and diversity, (d) the adoption of an anti-disruption policy measure designed to effectively and forcefully prohibit students and faculty from disrupting or blocking scheduled speeches and events on campuses. Any university that meets all these four conditions will be awarded an A grade. Based on this methodology and grading scheme, only six universities (Dalhousie, McMaster, St. Thomas, Lethbridge, Regina, and Windsor) earned ' $A$ ' grade and thirteen universities received ' $F$ ' grade in 2020 because they did not 
even meet one of those four criterial. Thus, the findings by Campus Freedom Index reinforce the alleged existence of challenges to the free speech in the Canadian higher educational institutions.

The findings in 2020 Campus Free Speech Index report are also corroborated and reinforced by another major study done for the Centre for the Study of Partisanship and Ideology. Eric Kaufman, the author of this major report bases his study on eight comprehensive surveys of academic and graduate student opinions across United States, Canada, and Britain (Kaufman, 2021). This report provides detailed information and hard data on the curtailment of viewpoint diversity, self-censorship of views in both teaching and research, and growing political discrimination against Conservative and gender -critical feminist scholars across these three Anglo-Saxon countries. However, the scale of hostility towards Conservative faculty, Conservative graduate students, and critical gender feminists is more pronounced in United States and Britain than in Canada.

Furthermore, in a survey of 16000 undergraduate students across Canada, it was found that university campuses were more receptive to liberal views than Conservative views, and almost $52 \%$ of students believed that their university campuses are not conducive to fostering the free flow of ideas (Brownell, 2019). Such a feeling was felt much stronger among Conservative oriented students than liberal oriented students ( $73 \%$ and $47 \%$ respectively).

The reports of sporadic free speech incidents on university campuses which have also stirred up sensational reports by the media, have triggered responses from certain Conservative provincial governments in Canada. Upon its accession of power in 2018, Conservative government of Dough Ford issued a directive titled "Upholding Free Speech on Ontario's University and College Campuses' to universities and colleges within province to come up with a comprehensive free speech policy by January 2019 (Office of the Premier, 2018). In line with its policy directive, Ontario provincial government has set up a government agency, the Higher Education Quality Council of Ontario (HEQCO), which is mandated to monitor free speech policy across universities and colleges, and report on their policy compliance to the government. According to this policy directive, universities and colleges are required to design their free speech policy in a manner that must meet minimum standards specified by government. If university administrators fail to comply with government's policy directive, their funding will be subject to cut back. It should be clarified that Ontario government's directive recognizes certain limitations on free speech particularly, speech that violates the law or actions that disrupt the normal operation of universities.

Following the footsteps of Premier Ford in Ontario, the Conservative administration in Alberta has also called on colleges and universities in Alberta to safeguard and strengthen freedom of expression on their campuses by adopting the Chicago Statement or designing a free speech policy in line with the spirit of the Chicago Statement (Government of Alberta, 2019). (Note 1) The reaction by Conservative administrations in Ontario and Altera has also been echoed by Quebec's Premier, François Legault who has associated the problem on universities campuses with "handful of radical activists who are trying to censor certain words and works" (Montpetit, 20121, para, 4). In parallel to the course of action taken by Conservative governments in Alberta and Ontario, Quebec Premier has also declared his commitment to put in place strong measures to protect freedom of expression in Quebec universities (Montpetit, 2021).

The attempt by Conservative governments in Ontario and Alberta to require universities and colleges to develop a free speech policy in line with governments' policy directives is not only construed as an interference in institutional autonomy of universities and colleges but is also seen as a calculated endavour to strengthen the Conservative basis in the higher educational settings (Turk, 2020). Furthermore, James Cameron (2020) has also argued that the free speech policy directives imposed by Conservative governments in these two provinces can be interpreted as a violation of the Charter since these free speech policy requirements constitute a forced expression. However, as Stephen Newman (2020) has pointed out, “...there is nothing inherently wrong with having a provincial government take steps to protect the exercise of fundamental rights ..." in the higher educational institutions during the time where there is an uncertainty over whether Charter can be applied to these educational settings (p.23).

Forced expression is a clear violation of the freedom of expression set out in section 2(b) of the Charter as the Supreme Court pointed out in its rulings in Ford v. Quebec (1987) and R.I.R. MacDonald (1995). However, regardless of the nature of intention lurking beneath the course of action taken by provincial governments in Ontario and Alberta, their free speech policy requirements can hardly be interpreted by the Court as forced expression since these directives do not impose ideological uniformity. These free speech policy directives are in fact intended to make sure universities and colleges create a vibrant learning environment within which diverse ideas and perspectives can be freely expressed as long as those expressed ideas do not infringe the law. 


\section{Balancing, Diversity, Inclusion and Free Speech}

Prior to analyzing the institutionalization of academic freedom in the Canadian higher educational institutions, it is essential to reflect on the interplay of academic freedom and freedom of expression which are the central themes in this paper. While these two concepts can be analyzed separately, they are nonetheless intrinsically complementary.

Freedom of expression is one of the most treasured civil liberties in liberal democratic societies. Since its entrenchment in the Article 19 of the 1948 Universal Declaration of Human Rights, the right to free speech and expression has been recognized in almost all international conventions and treaties (Howie, 2018), In Canada, freedom of expression is defined in section 2(b) of the Canadian Charter of Rights and Freedoms as "Freedom of thought, belief, opinion, and expression, including freedom of the press and other media of communication".

In its interpretation of freedom of expression, the Supreme Court of Canada has utilized content neutrality as a governing principle which implies that "the content of a statement cannot deprive it of the protection accorded by s. 2 (b), no matter how offensive it may be" (cited in Hogg, 2011, p. 43.5). Despite its constitutional protection, freedom of expression is not absolute since it is subject to reasonable limits specified in the section 1 of the Charter. Furthermore, freedom of expression is subject to certain limitations imposed by various Canadian laws on areas such as hate speech, obscenity, and defamation. Though Supreme Court Justices have exhibited their utmost commitment to the preservation of freedom of expression, they have nonetheless upheld restrictions on freedom of expression in several court cases such as R. v. Keegstra: R.v. Butler; R.v. Sharpe; and Little Sisters Books and Art Emporium v. Canada (Hogg, 2011).

There are three main overarching arguments that have been deployed in favour of the constitutional protection of the freedom of expression, which have also been echoed by the Supreme Court Justices on different occasions. First, the decisive contribution of freedom of expression to the maintenance of a democratic government is beyond dispute. It is beyond human imagination to talk of democratic government without the protection of the freedom of expression which as the Supreme Court has pointed out, is a prerequisite for the exercise of certain fundamental rights such as freedom of assembly, association, and voting. The relation of freedom of expression to democracy is to the relation between sun and a living organism. This fundamental rationale for the protection of the freedom of expression as an instrument of democratic government was meticulously articulated by Justice Ivan Rand in Switzman v. Elbling case (1957):

Whatever the deficiencies in its working, Canadian government is substance the will of the majority expressed directly or indirectly through popular assemblies. This means ultimately government by the free public opinions of an open society, the effectiveness of which, as events have not infrequently demonstrated, is undoubted.

But public opinion, in order to meet such a responsibility, demands the condition of a virtually unobstructed access to and diffusion of ideas. Parliamentary government postulates a capacity in men, acting freely and under self-restraints, to govern themselves, and that advance is best served in the degree of achieved of individual liberation from subjective as well as objective shackles (Para, 75\& 76)

Second, freedom of expression is hailed as an instrument of the truth. This argument in favour of the constitutional protection of the freedom of expression was articulated by John Stuart Mill who forcefully asserted that truth can only be discovered through the collision of opposing ideas. In Chapter II of On the Liberty, John Stuart Mill aptly pointed out the indispensability and imperative of the protection of the freedom of expression to the discovery of the truth:

The peculiar evil of silencing the expression of an opinion is that it is robbing the human race; posterity as well as the existing generation; those who dissent from the opinion, still more than those who old it; If the opinion is right, they are deprived of the opportunity of exchanging error for the truth; if wrong, they lose, what is almost as great a benefit, the clearer perception and livelier impression of truth produced by its collision with error( $\mathrm{Ch} 2$, para. 1)

Third, protection of freedom of expression is deemed to be sine quo non to the preservation of individual autonomy and individual self-development. According to this line of reasoning, fostering self-growth and self-actualization necessitates the creation of an environment where individuals can freely express themselves and receive the expression of others without fear of reprisal (Moon, 1985). Since Supreme Court of Canada has construed expression as any communicative activity that conveys a meaning, freedom of expression, therefore, encompasses not only 
speech but also all other human activities such as dancing, singing, painting, protesting, and picketing (Hogg, 2011, 43-7, 43-8).

Mill's rationalization for the protection of freedom of expression clearly denotes the innate affinity between freedom of expression and academic freedom. However, while freedom of expression is protected in the Charter, academic freedom is mainly protected through collective bargaining mechanisms. It is therefore, argued that since higher educational institutions are private entities and are not part of government, they are immune from the application of the Charter. This line of interpretation mainly rests on the Supreme Court's ruling in McKenny v. University of Guelph (1990). (Note 2) Though the Supreme Court has yet to clarify its stance on whether universities are carrying out governmental mandate and hence can be subject to the application of the Charter, the Supreme Court's rulings in Dore v. Barreau du Quebec (2012), and Loyola High School v. Quebec (2015), suggest that administrators who make decision pursuant to a statutory authority "which include many university administrators" are required to make sure their administrative decisions that limit individual's freedom of expression are justifiable (Rogers \& Taylor, 2018).

The assertion that universities fall outside of the Charter has been questioned by the recent ruling by the Alberta Court of Appeal, which demystified the claim that universities are Charter free zone. In her ruling in Pridgen $v$. University of Calgary (2012), Madam Justice Marina Paperny from Alberta Court of Appeal, shed light on the inherent affinity between academic freedom and freedom of expression. According to justice Paperny, there is "no legitimate conceptual conflict between the two concepts and both are handmaidens to the same goals" (para.117). Justice Paperny went on to argue that it is also questionable to assume that the application of Charter to higher educational institutions culminates in diminishing their institutional autonomy from government (para, 119). In her ruling, justice Paperny asserted that academic freedom understood as fearless pursuit of knowledge and propagate of ideas does not trump the exercise of freedom of expression because they both are inextricably linked rather than being in competition with one another (para. 114\&117). Finally, Justice Paperny elucidated the societal advantages of the application of Charter protected rights to the higher educational institutions.

One can no longer maintain a pastoral view of university campuses as a community of scholars removed from the rest of society. This does not mean a university should not be able to direct its own affairs, certainly in academic matters, free from government interference. It should. Respecting Charter rights in disciplining students will not, in my view, inhibit it in the exercise of that institutional independence or the exercise of academic freedom. Rather, it will promote the institution as a place of discourse, dialogue, and the free exchange of ideas; all the hallmarks of a credible university and the foundation of a democratic society (Para, 122).

Though the ruling by Alberta Court of Appeal is applicable to universities and colleges in the province of Alberta, it will nonetheless encourage student associations, faculty, and civil libertarian groups in other provinces to bring similar cases to the courts. Furthermore, the application of the Charter to universities and colleges also addresses the deficiency of the prevailing academic freedom principle which does not take into consideration the free speech rights of students. As one of the pillars of governance structure in Canadian universities, academic freedom has come to cement itself as a foundational value in the higher educational institutions. Academic freedom only covers the rights of faculty to freely teach, conduct research and criticize university administrators without fear of retaliatory sanctions. However, it is reticent on the free speech rights of students. The extension of the freedom of expression to the higher educational settings not only buttresses academic freedom but also protects students' free speech rights on campuses. A constitutionally protected freedom of expression is in fact conducive to galvanizing the full realization of the academic freedom. As is the case, academic freedom should not be construed as a part of negotiated fringe benefits for educators since its preservation is a prelude to the fulfillment of the higher educational institutions' fundamental mission of advancing a healthy, productive, and vibrant society. In other words, academic freedom will be further fortified when it is protected by the constitutionally protected freedom of expression.

The application of the Charter to the Canadian higher educational institutions might in fact assuage the tension between promoting inclusion, diversity, and upholding free speech principles that Canadian universities and colleges have sedulously been striving to address. Inclusion and freedom of expression should not be envisaged as mutually exclusive principles. Diversity and inclusion are promoted when diverse perspectives and ideas are allowed to be expressed. James Turk has clarified how the suppression of ideas can in fact complicate the societal quest for promoting diversity and inclusion:

If you silence those you find offensive, you diminish your ability to be critical or to articulate why it bothers you. When I talk about something a lot, I get better at being able to 
articulate precisely what it is that bothers me (cited in Grady, 2021, para. 16)

\section{Conclusion}

As has been demonstrated throughout this paper, like their American and European counterparts, Canadian university campuses have also become the sites for ideologically and politically motived debates over the state of free speech. While it was the Leftist progressive forces which exerted enormous pressure on universities and colleges to institutionalize academic freedom during the second part of the twentieth century, it is now Conservative and libertarian scholars and groups who lament the eclipse of freedom of expression from university campuses. Canadian universities have encountered a perplexing conundrum. While they are committed to promote diversity and inclusion, they are also expected to safeguard the free exchange and expression of ideas. Advancing inclusion and uploading free speech should not be characterized as opposing principles. They are in fact complementary. The tension between respecting diversity and free speech can to a great extent be mitigated by the extension of constitutionally protected freedom of expression to the Canadian higher educational institutions. The Application of the Charter protected freedom of expression to Canadian campuses is not only geared to address the shortcomings of the academic freedom principle that fails to cover students' right to freedom of expression but is also conducive to galvanizing and buttressing academic freedom itself. The extension of the Charter to the Canadian educational institutions does not necessarily diminish the ability of these educational institutions to develop robust policy measures that can effectively deal with unlawful expression and activities, which are intended to disrupt their routine operation.

\section{Notes}

Note 1. The Chicago Statement which contains principles that are widely recognized as gold standard of institutional policy directive on free speech which make it clear that Chicago "University's fundamental commitment is to the principle that debate, or deliberation may not be suppressed because the ideas put forth are thought by some or even by most members of the University community to be offensive, unwise, immoral, or wrong-headed." However, "The University may restrict expression that violates the law, that falsely defames a specific individual that constitutes a genuine threat or harassment, that unjustifiably invades substantial privacy or confidentiality interests, or that is otherwise directly incompatible with the functioning of the University".

https://provost.uchicago.edu/sites/default/files/documents/reports/FOECommitteeReport.pdf

Note 2. In this case, free speech was not the legal issue. The main issue was a challenge to mandatory retirement and whether universities are private entities or part of government.

\section{References}

Alberta Court of Appeal. Pridgen v. University of Calgary. (2012). https://www.canlii.org/en/ab/abca/doc/2012/2012abca139/2012abca139.html

Brodie, I. (2019). Taking on Repressive Tolerance at Canada's Universities. C2C Journal, March 6. https://c2cjournal.ca/2021/03/taking-on-repressive-tolerance-at- canadas-universities/

Brownell, C. (2019). Freedom of Speech on Campus: Our Survey of Canadian Students. Maclean's, Oct 30. https://www.macleans.ca/education/freedom-ofspeech-on-campus our-survey-of-canadian-students/

Cameron. J. (2020). Compelling Freedom on Campus: A Free Speech Paradox. Constitutional Forum, 29(2), 5-18. https://doi.org/10.21991/cf29395

Davis, B. (2015). Governance and Administration of Postsecondary Institutions in Canada. In Shanahan, T., Nilson, M., and Broshko, L.J. (Eds). Handbook of Canadian Higher Education Law, (pp. 57-78). Montreal: McGill-Queen's University Press.

Davis, W. (2018). The Free Speech Panic: How the Right Concocted a Crisis. The Guardian, July 26. https://www.theguardian.com/news/2018/jul/26/the-free-speech-panic-censorship-how-the-right-concocted-a-cr isis

Dea, S. (2018). A Brief History of Academic Freedom. University Affairs. https://www.universityaffairs.ca/opinion/dispatches-academic-freedom/a-briefhistory-of-academic-freedom/

Franks, M. A. (2019). The Miseducation of Free Speech. Virginia Law Review online, 105, 218-242. https://www.virginialawreview.org/wp-content/uploads /2020/12/Franks_Book.pdf

Government of Alberta. (2019). Enhancing Free Speech on Campuses. Dec 17. https://educationnewscanada.com/article/education/level/university/1/807304/ehancing-free-speech-on campu-ses.html 
Grady, M. (2021). Defending Diversity and Academic Freedom. Ryerson Today, Jan 26. https://www.ryerson.ca/news-events/news/2021/01/defending-diversity and-academic-freedom/

Heron, G. (2015). The Miseducation of Free Speech. Virginia Law Review Online, 105, 218-242. https://www.virginialawreview.org/articles/miseducation-freespeech/

Hogan, B. E., \& Trotter, L. D. (2013). Academic freedom in Canadian higher education: Universities, colleges, and institutes were not created equal. Canadian Journal of Higher Education, 43(2), 68-84. https://doi.org/10.47678/cjhe.v43i2.2427

Horn, M. (1999). Academic Freedom in Canada: A History. Toronto: University of Toronto Press. https://doi.org/10.3138/9781442670570

Horn, M. (1994). Unionization, and the Canadian University: Historical and Personal Observations. Interchange, 25, 39-48. https://doi.org/10.1007/BF01447191

Howie, E. (2018). Protecting the Human Right to Freedom of Expression in International Law, International Journal of Speech-Language Pathology, 20(1), 12-15. https://doi.org/10.1080/17549507.2018.1392612

Johnston, D. J. (2017). Open Access Policies and Academic Freedom: Understanding and Addressing Conflicts. Journal of Librarianship and Scholarly Communication, 5(General Issue), $104 . \quad 1-17$. http://doi.org/10.7710/2162-3309.2104

Jones, G., Shanahan, T., \& Goyan, P. (2010). University Governance in Canadian Higher ～Education. Tertiary Education and Management, 7(2), 135-148. https://doi.org/10.1080/13583883.2001.9967047

Kaufman, E. (2021). Academic Freedom in Crisis: Punishment, Political Discrimination, and Self-Censorship, Center for the Study of Partisanship, and Ideology. Report No 2, March 1. https://cspicenter.org/reports/academicfreedom/

Lynx, M. (2020). Academic Freedom, Canadian Labour Law, and the Scope of Intra Mural Expression. Constitutional Forum, 29(2), 45-64. https://doi.org/10.21991/cf29399

Malik, N. (2019, September 3). The Myth of the Free Speech Crisis. The Guardian, Sept 3. https://www.theguardian.com/world/2019/sep/03/the-myth-of-the-free-speechcrisis

Montpetit, J. (2021, February 18). In Vow to Protect Campus Free Speech, Quebec Premier Joins 'War on Woke'. $C B C$, Feb https://www.cbc.ca/news/canada/montreal/quebec-campus-free-speech-academic-freedom-legault-1.5917113

Marshall, D. B. (1994). Canadian Historians, Secularization, and the Problem of the Nineteenth Century. CCHA, Historical Studies, $\quad 60, \quad 57-81$. https://umanitoba.ca/colleges/st_pauls/ccha/Back\%20Issues/CCHA199394/Marshall.pdf

Mill, J. S. (1859). On Liberty; Chapter II. https://www.utilitarianism.com/ol/two.html

Moon, R. (1985). The Scope of Freedom of Expression. Osgoode Hall Law Journal, 23(2), 331-357. http://digitalcommons.osgoode.yorku.ca/ohlj/vol23/iss $2 / 5$

Myles, R. (2018). Academic Freedom Versus Freedom of Expression. Summit. Spring/Summer Issue. https://www.mtroyal.ca/Summit/academic-freedom.htm

Newman, S. L. (2020). The Politics of Campus Free Speech in Canada and the United States. Constitutional Forum, 29(2), 19-30. https://doi.org/10.21991/cf29397

Office of the Premier. (2018). Upholding Free Speech on Ontario's University and College Campuses, Aug 30. https://news.ontario.ca/en/backgrounder/49950/upholding-freespeech-on-ontarios-university-and-college-cam-p uses

Robinson, D. (2019). Academic Freedom in Canada: A Labor Law Right. American Association of University Professors (AAUP). https://www.aaup.org/article/academic-freedom-canada-labor-law-right\#. YNCoiehKiUk

Rogers, R., \& Taylor, J. (2018). Canada: An Update on Freedom of Expression \& Charter Application to Universities. Mondaq. https://www.mondaq.com/Home/About

The Justice Centre for Constitutional Freedom. (2020). 2020 Campus Free Speech Index. https://campusfreedomindex.ca/2020-campus-freedom-index/ 
Turk, J. L. (2020). Universities, the Charter, Doug Ford, and Campus Free Speech. Constitutional Forum, 29(2), 31-45. https://doi.org/10.21991/cf29398

Weismiller, B. (2011). Free Speech Under Serious Attack at Canadian Universities, Conference Told. National Post, Oct

https://nationalpost.com/news/canada/free-speech-under-serious-attack-at-canadian-universities-conferencetold

\section{Copyrights}

Copyright for this article is retained by the author(s), with first publication rights granted to the journal.

This is an open-access article distributed under the terms and conditions of the Creative Commons Attribution license (http://creativecommons.org/licenses/by/4.0/). 